\title{
Ale beer containing free and immobilized Lactobacillus brevis, a potential delivery system for probiotics
}

\author{
Kriza Faye Calumba', Vondel Reyes ${ }^{1}$, Franklin Bonilla ${ }^{1}$, Elio Villasmil ${ }^{1}$ and Subramaniam Sathivel ${ }^{1,2^{*}}$
}

\begin{abstract}
Probiotics in ale beer may be attractive to health-conscious consumers. However, beer conditions may decrease probiotic viability. Powder produced from durian (Durio zibethinus) rind, a by-product that is currently unutilized, can be used for the immobilization of probiotics. MRS medium was incubated with Lactobacillus brevis and periodically sampled to obtain the growth curve. Ale beer with free L. brevis and cells immobilized in durian rind powder was produced and separately assessed during storage at $21{ }^{\circ} \mathrm{C}$ for 24 days. The physico-chemical parameters of both beers did not differ significantly. Durian rind powder conferred protection up to 12 days of storage with the immobilized cells in the beer having a significantly higher count than the free cells, which can be due to the acid detergent fiber content (19.67\%). Free and immobilized cells remained viable with counts of 4.89 and $5.00 \log \mathrm{CFU} / \mathrm{mL}$ of beer, respectively, at the end of the storage period. Both treatments had approximate counts of $5 \log \mathrm{CFU} / \mathrm{mL}$ after $120 \mathrm{~min}$ in simulated gastric and intestinal fluids. The predominant bacterial species present at the end of storage were L. brevis and L. farciminis. This study suggests that ale beer could be a potential delivery system for free and immobilized probiotic bacteria. This is one of the few studies demonstrating the use of probiotic lactic acid bacteria in beer brewing.
\end{abstract}

Keywords: Probiotics, Beer, Durian, Viability

\section{Introduction}

The increasing awareness about the importance of a healthy diet has driven the market for health-oriented food and beverages (Augustin and Sanguansri 2015). Probiotic products have gained interest throughout the years because of their reported role in immunological, digestive, and respiratory health and in easing infectious diseases (Vasudha and Mishra 2013). Probiotics are defined by the Food and Agriculture Organization and World Health Organization (2002) as "live microorganisms which when administered in adequate amounts confer a health benefit on the host." Probiotics are thought to confer health benefits primarily through

\footnotetext{
* Correspondence: ssathivel@agcenter.Isu.edu

'School of Nutrition and Food Sciences, 220 H.D. Wilson Laboratories, Louisiana State University Agricultural Center, Baton Rouge, LA 70803, USA ${ }^{2}$ Department of Biological and Agricultural Engineering, Louisiana State University, Baton Rouge, LA 70803, USA
}

modulating the immune system of the intestine and displacing pathogens such as Salmonella typhimurium, Helicobacter pylori, and Escherichia coli (Govender et al. 2014; Hove et al. 2014).

While most probiotic products available are dairy, alternative raw materials are being investigated (Vasudha and Mishra 2013). Allergy and lactose intolerance are considered as the major disadvantages of dairy probiotic products, whereas probiotic survival poses a huge challenge when dealing with non-dairy foods (Vijaya Kumar et al. 2015). One possible probiotic drink is beer which is the most consumed alcoholic drink globally and the third most popular drink after water and tea. To date, only one study has investigated the survival of probiotic bacteria in a novel beer product (Alcine Chan et al. 2019). The worldwide production of beer is estimated to be 1.7 billion liters per year (Colen and Swinnen 2016;

(c) The Author(s). 2021 Open Access This article is licensed under a Creative Commons Attribution 4.0 International License, which permits use, sharing, adaptation, distribution and reproduction in any medium or format, as long as you give appropriate credit to the original author(s) and the source, provide a link to the Creative Commons licence, and indicate if changes were made. The images or other third party material in this article are included in the article's Creative Commons licence, unless indicated otherwise in a credit line to the material. If material is not included in the article's Creative Commons licence and your intended use is not permitted by statutory regulation or exceeds the permitted use, you will need to obtain permission directly from the copyright holder. To view a copy of this licence, visit http://creativecommons.org/licenses/by/4.0/. 
Martínez et al. 2017). China and the USA are the top two beer-producing countries in the world followed by Germany, Brazil, and Russia, all accounting for more than half of the total output (da Silva et al. 2008). Moreover, the consumption of alcoholic drinks has been linked to the disruption of intestinal microbiome homeostasis in both rodent models and humans (Engen et al. 2012). Alcoholic drinks influence gut microbiota and gut inflammations (Bishehsari et al. 2017).

Microorganisms including probiotic bacteria are generally susceptible to stress conditions (G-Alegría et al. 2004). Alcohol is reported to cause cell death by increasing membrane fluidity, thereby inhibiting microbial cell growth (Jia et al. 2010). However, gram-positive bacteria, especially lactic acid bacteria, are known to survive and grow in the presence of high alcohol concentrations (Jia et al. 2010). The genus Lactobacillus generally manifests significant ethanol tolerance when grown in the presence of up to $16 \%$ ethanol by volume (Gold et al. 1992). In addition, the Lactobacillus brevis species used in the study carried out by Knoshaug and Zhang (2009) manifested growth in environments with up to $3 \%$ butanol. According to the Beer Judge Certification Program (2015), the alcohol percent by volume of blonde ale beer that is the type of beer produced in this study is between 3.8 and 5.5\% which is lower than the alcohol concentration $(16 \%, \mathrm{v} / \mathrm{v})$ the L. brevis was exposed to in the study of Gold et al. (1992). Therefore, Lactobacillus brevis was selected in the current study.

Incorporating probiotics in beer will potentially confer health benefits that typical beer in the market cannot provide. However, the presence of hop iso- $\alpha$-acids in beer is also detrimental to the survival of probiotics (Alcine Chan et al. 2019), signifying the need for some support. The study of Alcine Chan et al. (2019) aimed to overcome the antimicrobial effect of hops iso- $\alpha$-acids by carrying out first a co-fermentation step through coculturing the starter culture L. paracasei L26 with $S$. cerevisiae S-04 in unhopped wort for 10 days. Isomerized hop extract was then added to the co-culture and the viability was evaluated at 5 and $25{ }^{\circ} \mathrm{C}$ during 28 days of storage. According to the authors, during this co-fermentation step, yeasts may help protect the probiotic bacteria due to the formation of mixed-species biofilms that have been demonstrated in other acidic food products. Moreover, immobilization, which refers to the trapping of material in a matrix, has been shown to improve the survival and growth of probiotics in various products (Mitropoulou et al. 2013). Several immobilization supports have been considered with a particular preference for biopolymers and natural supports that are food-grade (Mitropoulou et al. 2013). In a recent study, hi-maize starch, which behaves similarly to fiber, was used to immobilize probiotics (Bradford et al. 2019).
Durian (Durio zibethinus) is one of the most popular tropical fruits in Southeast Asia (Espino and Espino 2014). Only one-third of the fruit is consumed, with the fiber-rich rind comprising more than half of the total fruit weight (Hameed and Hakimi 2008; Penjumras et al. 2014). Since direct disposal of durian wastes causes social and environmental issues (Nuithitikul et al. 2010), utilizing them could provide economic value. Teh et al. (2009) evaluated durian rind, along with that of mangosteen and jackfruit, as immobilizers for probiotics in soy milk. In the current study, powder produced from durian rind was used as immobilization support for probiotic bacteria in beer. This study aimed to produce ale beer with either free Lactobacillus brevis or immobilized cells on durian rind powder to serve as a delivery system for probiotics.

\section{Materials and methods Microorganism}

A lyophilized strain kindly provided by the USDA Agricultural Research Service Culture Collection (Washington, DC, USA) was identified as Lactobacillus brevis using $16 \mathrm{~s}$ rRNA sequencing (MR DNA, Shallowater, TX, USA). The culture was activated in De Man, Rogosa, and Sharpe (MRS) broth (Neogen Corporation, Lansing, MI, USA). For the free cells, seventy-five $\mathrm{mL}$ of the culture was inoculated in $1.5 \mathrm{~L}$ MRS broth and incubated at $37^{\circ} \mathrm{C}$ for $16 \mathrm{~h}$ to reach stationary phase and to achieve a minimum cell count of $8.0 \log \mathrm{CFU} / \mathrm{mL}$. The cultures were harvested by centrifugation at $7500 \mathrm{x}$ g for $10 \mathrm{~min}$ at $4{ }^{\circ} \mathrm{C}$ (Beckman J2-HC, Beckman Coulter, Inc., Brea, CA, USA). The pellets were washed twice with sterile $0.85 \% \mathrm{NaCl}$ solution, centrifuged, and suspended in sterile distilled water.

\section{Growth curve and growth parameters}

One $\mathrm{mL}$ of $L$. brevis was inoculated in $100 \mathrm{~mL}$ of MRS broth and incubated at $37^{\circ} \mathrm{C}$ for $24 \mathrm{~h}$. A growth curve was constructed by measuring the optical density at 600 $\mathrm{nm}\left(\mathrm{OD}_{600}\right)$ of the cell culture using a spectrophotometer (Genesis 20, Thermo Scientific Instruments, LLC, Madison, WI, USA). The absorbance was correlated with the concentration acquired ( $X$, expressed in $\mathrm{g} / \mathrm{L}$ ) using the equation obtained from the standard curve. The maximum cell density $\left(\mathrm{OD}_{\max }\right)$, maximum concentration $\left(X_{\max }\right)$, maximum specific growth rate $\left(\mu_{\max }\right)$, and doubling time $\left(\mathrm{T}_{\mathrm{d}}\right)$ were obtained as described by Mis et al. (2019).

\section{Preparation of durian rind powder}

Frozen durian fruit (Durio zibethinus), Mornthong variety (Thailand), was purchased from a local Asian store in 2017 (Baton Rouge, LA, USA). The whole fruit was thawed, cut using a knife to obtain the thorn-covered 
rind, after which the thorny part was removed. The rind portions were sliced into smaller pieces before ovendrying at $70^{\circ} \mathrm{C}$ for $20 \mathrm{~h}$. The dried rind was ground for 10-12 min using a commercial blender to obtain the durian rind powder (DRP) which was sieved through a Tyler Standard Screen No. 48 (W.S. Tyler, Mentor, OH, USA). The resultant powder with an average particle size of $295 \mu \mathrm{m}$ was stored at $4{ }^{\circ} \mathrm{C}$ until further use.

\section{Proximate analysis of DRP}

DRP was analyzed for moisture content, fat, protein, ash, and crude fiber. Moisture content was determined using a microwave-type moisture analyzer (Model 907,875, CEM Corporation, Inc., Matthews, NC, USA) (Reyes et al. 2018). Fat content was quantified using AOAC official method 2003.06 (AOAC 2006). For the protein analysis, the sample was digested following the EPA method 351.2 (EPA, 1993), then it was subjected to AOAC (1995) method 976.06. Ash content was measured using AOAC (1990) method 942.05. Crude fiber was analyzed by the filter bag technique using AOCS (2006) approved procedure $\mathrm{Ba}$ 6a-05.

\section{Preparation of immobilized Lactobacillus brevis}

DRP in MRS broth was sterilized in an autoclave before immobilization. After activating the culture in MRS broth, $75 \mathrm{~mL}$ was inoculated in $1.5 \mathrm{~L}$ sterile MRS broth with $15 \mathrm{~g}$ DRP to achieve a cell count of at least $8.0 \mathrm{log}$
CFU/mL. Immobilization was carried out through shaking at $150 \mathrm{rpm}$ using a shaker (Lab-line incubator shaker model 3525, Fisher Scientific Inc., Pittsburgh, PA, USA) at $37^{\circ} \mathrm{C}$ for $16 \mathrm{~h}$. The immobilized LB on DRP was washed twice with sterile $0.85 \% \mathrm{NaCl}$ solution, centrifuged at $7500 \mathrm{xg}$ for $10 \mathrm{~min}$ at $4{ }^{\circ} \mathrm{C}$ to obtain the pellets, and suspended in sterile distilled water.

\section{Scanning electron microscopy (SEM)}

SEM was carried out following the method of Reyes et al. (2018). The morphology of FLB and ILB was observed under a scanning electron microscope (JSM-6610LV, JEOL Ltd., Tokyo, Japan).

\section{Production of ale beer}

The ale beer was produced following the standard procedure described by Lordan et al. (2019) and Parker (2012) with some modifications. The production process for ale beer is outlined in Fig. 1. Pale malt extract (3.6 kg) (Alexander's Sun Country, CA, USA) was dissolved in $38 \mathrm{~L}$ of water in a brew kettle (Model MKEL100T, Cleveland Range Ltd., Toronto, ON, Canada) and brought to boiling. After $1 \mathrm{~min}$ of boiling, $12 \mathrm{~g}$ of pelleted hops (Northern Brewer, Roseville, MN, USA) was added for bitterness and flavor. After $15 \mathrm{~min}$ of boiling, $24 \mathrm{~g}$ hops was further added, and the remaining $12 \mathrm{~g}$ was added after another $15 \mathrm{~min}$ of boiling. The specific gravity (SG) was measured using a triple scale hydrometer

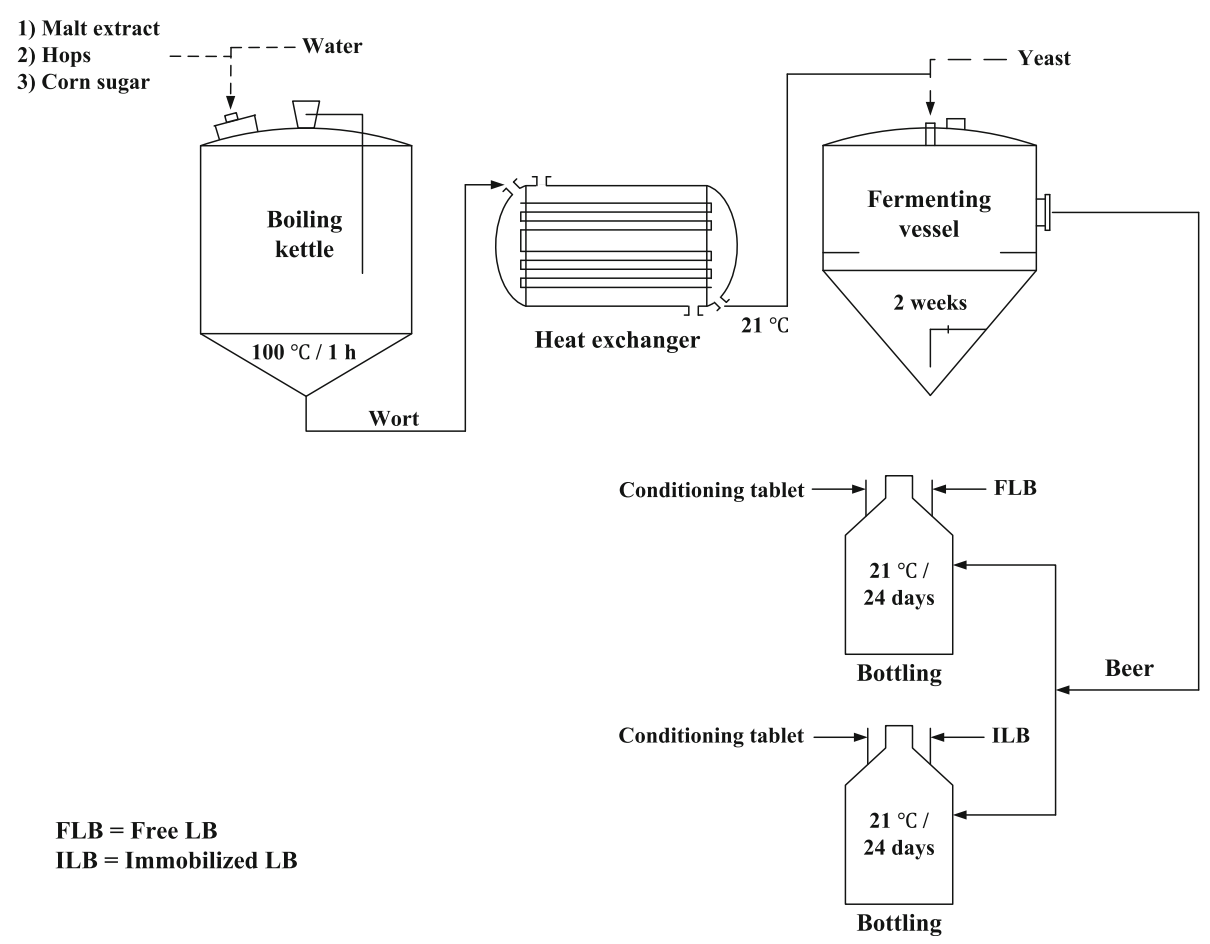

Fig. 1 Production of ale beer with FLB and ILB. FLB = free Lactobacillus brevis and ILB =immobilized Lactobacillus brevis 
(Alla France, Chemillé-en-Anjou, France). Corn sugar was added until an SG value of 1.040-1.060 was reached. The wort was transferred to a conical fermenter with a capacity of $26.5 \mathrm{~L}$ (SS Brewtech, CA, USA). It was then cooled to $21{ }^{\circ} \mathrm{C}$ using a VWR refrigerated recirculator (Model 1176, VWR Scientific, Niles, IL, USA). Once cool, dry brewing yeast (Saccharomyces cerevisiae) (SafAle S-3, Fermentis, France) was added to the wort. Fermentation was carried out for 2 weeks at $20^{\circ} \mathrm{C}$.

\section{Inoculation of FLB and ILB into beer}

Fifteen $\mathrm{mL}$ of the free cells (FLB) and immobilized cells (ILB) was separately inoculated in $285 \mathrm{~mL}$ of ale beer corresponding to counts of $8.92 \pm 0.04 \log \mathrm{CFU} / \mathrm{mL}$ and $9.94 \pm 0.04 \log \mathrm{CFU} / \mathrm{mL}$ of beer, respectively. A conditioning tablet made of dextrose was added during bottling to give carbonation. The beer was stored for 24 days at $21^{\circ} \mathrm{C}$ to simulate ambient storage. Ale beer with free cells was used as the control.

\section{Physico-chemical properties of beer}

Pure beer (without FLB and ILB) and beer with FLB and ILB were analyzed for specific gravity, total soluble solids, $\mathrm{pH}$, and titratable acidity. Specific gravity was measured using a triple scale wine and beer hydrometer (Alla France, Chemillé-en-Anjou, France). The SG of the wort (OG), as well as the final SG (FG) after yeast fermentation before the addition of probiotic bacteria, were used to calculate the alcohol percentage by volume $(\mathrm{ABV})$ of the beer.

Equation 1 was used with a value of approximately 0.79 as the specific gravity of alcohol (Brick 2006; Stange 2015). This formula considers $1.05 \mathrm{~g}$ of ethanol produced per gram of carbon dioxide lost during fermentation according to the chemical reaction. Dividing this value by 0.79 and multiplying by 100 yields 132.91 which is the factor used to calculate ABV.

$$
A B V=132.91(O G-F G)
$$

The total soluble solids as expressed in ${ }^{\circ}$ Brix were determined using a digital handheld refractometer (AR200, Reichert, Inc., Depew, NY, USA). pH was measured using an EcoSense $\mathrm{pH}$ pen (YSI Inc., Yellow Springs, $\mathrm{OH}, \mathrm{USA}$ ). Titratable acidity (TA) was determined using the method described by Mis et al. (2019). TA was expressed in terms of $\mathrm{mg} / \mathrm{mL}$ lactic acid.

Carbonation was also measured using a beer carbonation tester (Model 2701-BCT, Taprite, San Antonio, TX, USA) at 24 days of storage at $21^{\circ} \mathrm{C}$ for both beers inoculated with FLB and ILB.

\section{Viability of FLB and ILB in ale beer during storage at $21^{\circ} \mathrm{C}$}

Viability was measured on the free and immobilized cells every 3 days for 12 days, and then at 18 and 24 days. Beer samples were serially diluted in test tubes containing $0.85 \% \mathrm{NaCl}$ solution. An aliquot of $0.1 \mathrm{~mL}$ was inoculated into MRS agar using the pour plating technique and measurements were obtained in triplicate. After incubation at $37^{\circ} \mathrm{C}$ for $48 \mathrm{~h}$, Petri plates with $25-250 \mathrm{col}-$ onies were counted and the results were expressed as $\log \mathrm{CFU} / \mathrm{mL}$ of beer.

\section{Viability in simulated gastric and intestinal fluids of FLB and ILB in ale beer stored for 24 days at $21^{\circ} \mathrm{C}$}

The viability under simulated gastric and intestinal conditions was measured at 18 and 24 days of storage at $21{ }^{\circ} \mathrm{C}$. The simulated gastric fluid (SGF) and simulated intestinal fluid (SIF) solutions were prepared according to the method used by Roberts et al. (2018) with slight modifications. SGF was prepared by dissolving $0.5 \mathrm{~g}$ of $\mathrm{NaCl}$ and $1.5 \mathrm{~g}$ of pepsin in $1.75 \mathrm{~mL}$ of $12 \mathrm{M} \mathrm{HCl}$. The solution was diluted to $250 \mathrm{~mL}$ with sterile distilled water, adjusted to $\mathrm{pH} 3.0$, and passed through a sterile $0.22-\mu \mathrm{m}$ filter. The SIF solution was prepared by dissolving $1.7 \mathrm{~g} \mathrm{KH}_{2} \mathrm{PO}_{4}$ in $62.5 \mathrm{~mL}$ of water. Then, $19.25 \mathrm{~mL}$ of $0.2 \mathrm{~N} \mathrm{NaOH}$ was added and the solution was diluted to $250 \mathrm{~mL}$ with sterile distilled water. Pancreatin was added $(1 \% \mathrm{w} / \mathrm{v})$ and the $\mathrm{pH}$ was adjusted to 6.5 . The solution was filtered using a sterile $0.22-\mu \mathrm{m}$ filter. Beer samples of $1 \mathrm{~mL}$ each were separately introduced to 9 $\mathrm{mL}$ of pre-warmed SGF and $9 \mathrm{~mL}$ of pre-warmed SIF solutions and incubated at $37^{\circ} \mathrm{C}$ under constant agitation. Samples were collected at 30,60, and 120 min intervals for viability measurements. Results were expressed as $\log \mathrm{CFU} / \mathrm{mL}$ of beer.

\section{Microbial diversity of beer with FLB and ILB}

Beer samples with FLB and ILB were analyzed for bacterial and fungal diversity using bacterial tag-encoded FLX amplicon pyrosequencing (bTEFAP) as described previously by Dowd et al. (2008) (MR DNA, Shallowater, TX, USA). Samples were sequenced at MR DNA (www. mrdnalab.com, Shallowater, TX, USA) on an Ion S5 Next-Generation Sequencing System (Thermo Fisher Scientific, Inc., USA) following the manufacturer's guidelines. Sequence data were processed using a proprietary analysis pipeline (MR DNA, Shallowater, TX, USA).

Operational taxonomic units (OTUs) were defined by clustering at 3\% divergence ( $97 \%$ similarity). Final OTUs were taxonomically classified using BLASTn in comparison with a curated high-quality $16 \mathrm{~s}$ rRNA gene database derived from RDP-II (http://rdp.cme.msu.edu) and the National Center for Biotechnology Information (NCBI) (www.ncbi.nlm.nih.gov). Data were compiled and 
relative percentages of bacteria and fungi were determined for each beer sample.

\section{Statistical analysis}

Data from triplicate experiments were statistically analyzed using the Statistical Analysis System (SAS Version 9.2, SAS Institute Inc., Cary, NC, USA). An independent t-test was used to determine the significant differences between the two samples. Analysis of variance and Tukey's test as post-hoc at an alpha level of 0.05 were used to determine significant differences within each treatment through time.

\section{Results and discussion}

\section{Growth curve and growth parameters of Lactobacillus} brevis

The growth curve of L. brevis is shown in Fig. 2. The microorganism reached a maximum cell density $\left(\mathrm{OD}_{\max }\right)$ of $1.09 \pm 0.03$ and a maximum concentration $\left(X_{\max }\right)$ of $0.39 \pm 0.01 \mathrm{~g} / \mathrm{L}$ at $16 \mathrm{~h}$ of fermentation. The $\mathrm{OD}_{\max }$ was comparable to that of L. brevis S354 subjected to different carbon sources (Guo et al. 2010). In this study, stationary phase was reached after $16 \mathrm{~h}$ so the pellets were harvested at this time before adding to the beer. Moreover, $L$. brevis displayed a maximum specific growth rate $\left(\mu_{\max }\right)$ of $0.12 \mathrm{~h}^{-1}$ and a doubling time of $5.82 \mathrm{~h}$ based on concentration.

\section{Proximate composition of DRP}

As presented in Table 1, the major dry components of the DRP were acid detergent fiber (ADF) (19.67\%), crude fiber $(17.10 \%)$, ash $(6.06 \%)$, protein $(4.77 \%)$, and fat $(0.46 \%)$. Previous studies reported comparable values for the composition of durian peel (Foo and Hameed 2011; Unhasirikul et al. 2012). The main components of ADF
Table 1 Proximate composition of DRP

\begin{tabular}{ll}
\hline Composition & \% (wet basis) \\
\hline Protein & $4.77 \pm 0.58$ \\
Fat & $0.46 \pm 0.10$ \\
Crude fiber & $17.10 \pm 0.40$ \\
Acid detergent fiber $^{a}$ & $19.67 \pm 0.26$ \\
Carbohydrate $^{a}$ & $85.83 \pm 1.72$ \\
Ash & $6.06 \pm 0.98$ \\
Moisture & $2.89 \pm 0.27$
\end{tabular}

Values are means \pm standard deviations of triplicate measurements

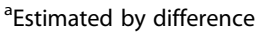

are homogeneous polysaccharides, which can easily undergo cleavage to produce monosaccharides. These, in turn, could serve as a fermentation substrate for the bacterial community in the gut and promote gut health (Zhao et al. 2019). Moreover, according to Madhu et al. (2017), crude fiber is predominantly $60-80 \%$ cellulose and $4-6 \%$ lignin plus some mineral matter. It was reported that dried durian peel had a high hemicellulose content at 15.5\% (Masrol et al. 2015). The forms of cellulose present in DRP could help improve probiotic stability by providing some protection as mentioned by Perricone et al. (2015). Nonetheless, the actual sugar composition of DRP should be evaluated in future research. It was also noted that the DRP had a minimal moisture content of $3.04 \%$ corresponding to a low water activity comparable to the results of Kha et al. (2010). This dictates good storage quality of the powder (Shyamala and Jamuna 2010).

\section{Scanning electron microscopy}

Scanning electron micrographs of FLB and ILB are shown in Figs. 3 and 4, respectively. Free cells appear to

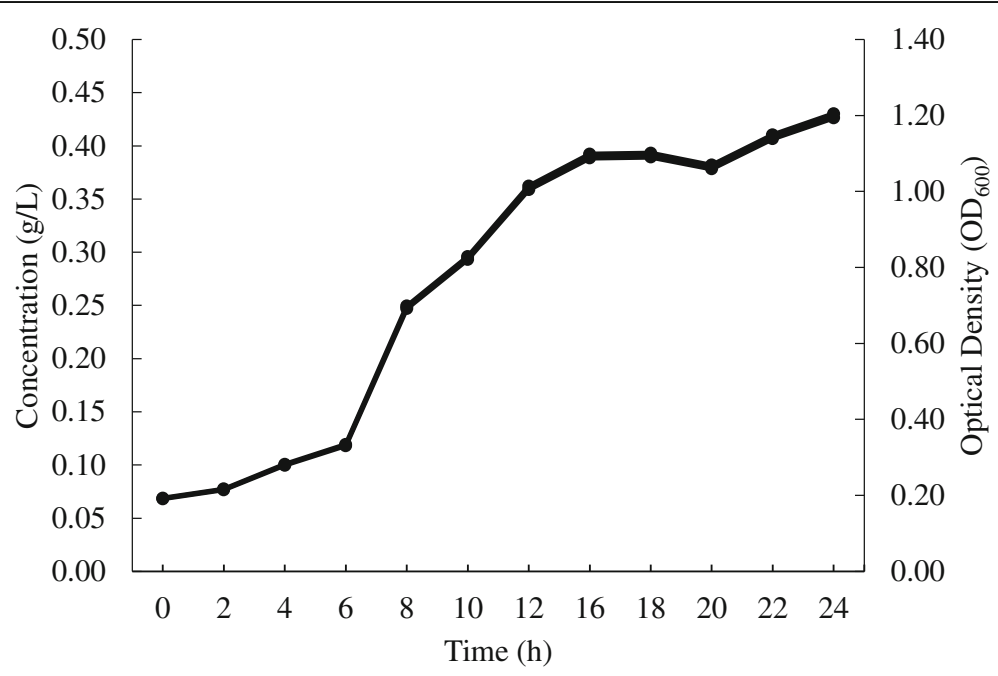

Fig. 2 Growth of Lactobacillus brevis measured as concentration $(\mathrm{g} / \mathrm{L})$ and optical density $\left(\mathrm{OD}_{600}\right)$ using MRS media 


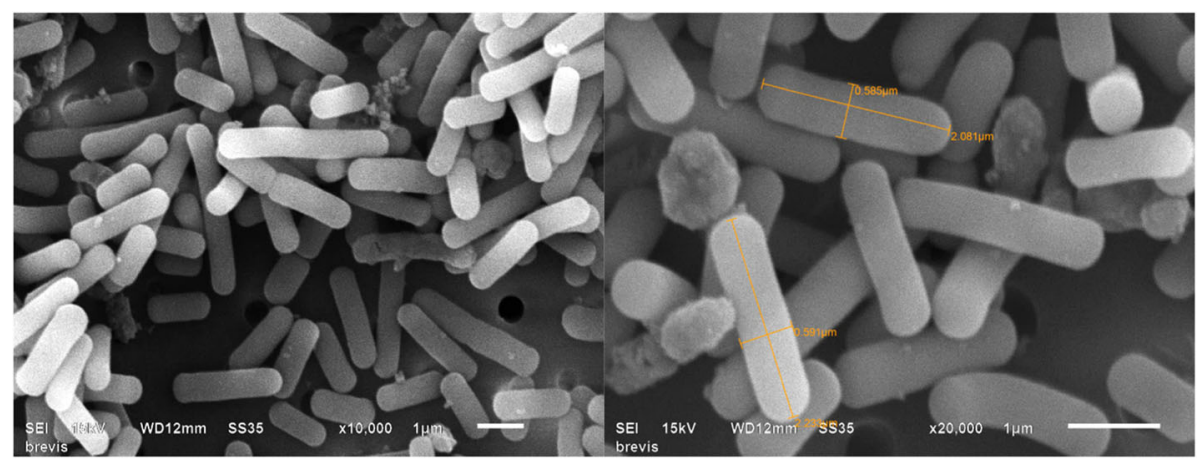

Fig. 3 Scanning electron micrographs of free L. brevis

have a rod shape (Fig. 3). This morphology agreed with the results of Kimoto-nira et al. (2015) and Elez-Martinez et al. (2005). As illustrated in Fig. 4a, it was evident that the bacterial cells were randomly distributed and attached to the DRP. This indicated that DRP could provide an adherence matrix for the probiotic bacteria. The DRP had rough and uneven surfaces to which the probiotic bacteria attached (Fig. 4b). The spaces introduced by the bumpy surface of the powder matrix provided room for the attachment of the probiotic as seen in a zoomed out micrograph in Fig. 4c with the encircled portion magnified as shown in Fig. 4d. Results were similar to those from a study by Jagannath et al. (2010) wherein the disorganized arrangement of cellulose strands were illustrated to hold many bacteria in the spaces and on the surface. Another study described the penetration of bacterial cells into the open pores of different immobilization matrices particularly inorganic porous supports (El Enshasy and Moawad 2011). In our study, the high number of cells attaching to the surface and going into open spaces signified immobilization of L. brevis on DRP. The adherence of probiotic cells on the powder despite several washings upon fixing the sample for SEM indicated sufficient immobilization, similar to the results of Xiudong et al. (2016).

Microorganisms such as probiotic bacteria adsorb spontaneously on various organic and inorganic supports with intermolecular forces of attraction responsible for

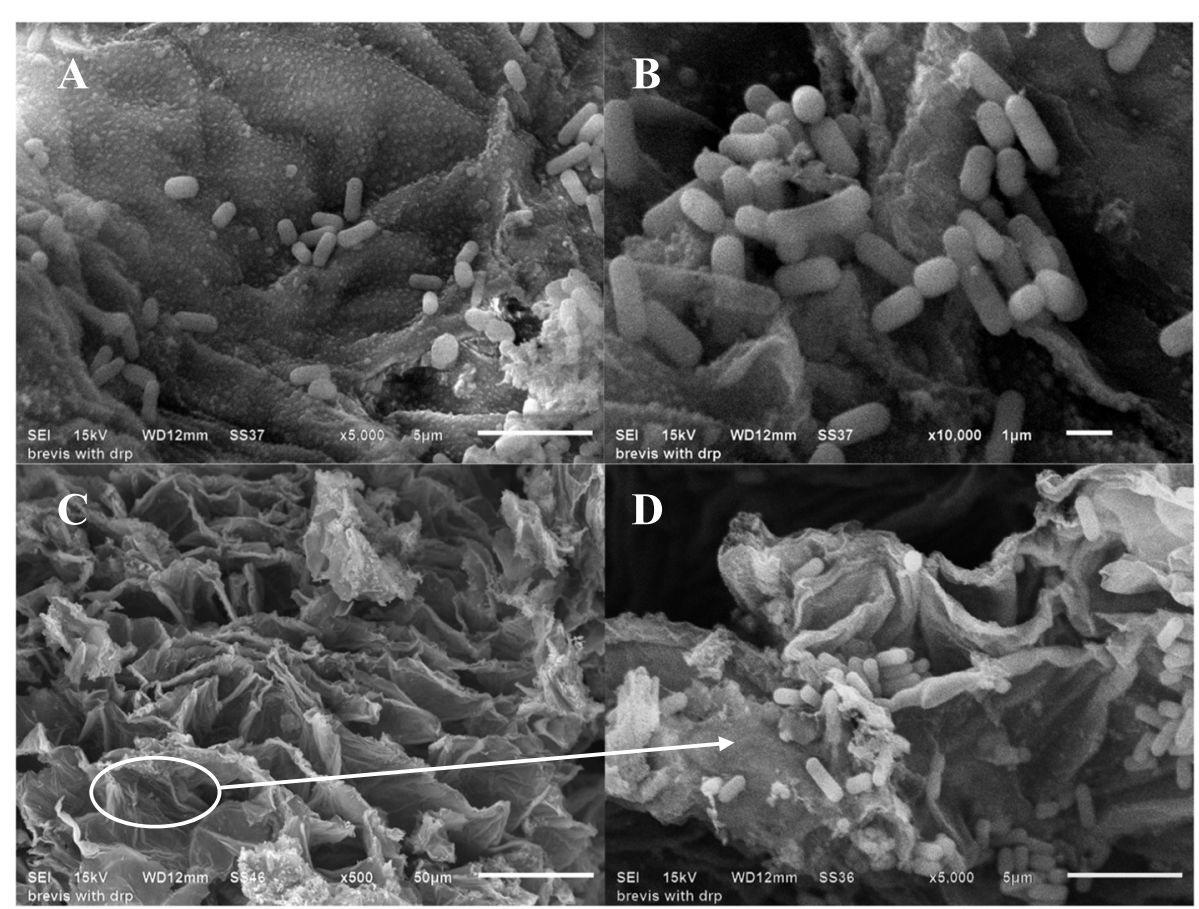

Fig. 4 Scanning electron micrographs of cross-sections of DRP loaded with L. brevis 
cell binding. Cell physiology greatly affects the strength of adhesion (Nedovic and Willaert 2005). As mentioned by Xiudong et al. (2016), covalent bonding or physical adsorption by electrostatic forces could be responsible for the immobilization of the probiotic. Also, Raghavendra et al. (2006) reported that grinding provides increased surface area for absorption, and the uneven surfaces shown in the SEM could have been produced by grinding the powder, thereby increasing available areas for attachment of $L$. brevis cells.

\section{Physico-chemical properties of ale beer}

In this study, the final carbonation of beer at 24 days of storage was 2.8 volumes $\mathrm{CO}_{2}$, which is characteristic for ales according to a chart set for the carbonation tester used (Model 2701-BCT, Taprite, San Antonio, TX, USA). A carbonation level of "2 volumes" implies 2 cubic inches of $\mathrm{CO}_{2}$ dissolved in every cubic inch of volume (Walsh et al. 2014). The level of $\mathrm{CO}_{2}$ dissolved in beer largely affects its flavor and visual appeal. Around 2.6 volumes have been recommended for carbonation in beer packages, while breweries employ 0.2 volumes higher to account for a possible loss during packaging (Rohner and Tompkins 1970). The carbonation level measured for the ale beer produced in this study corresponded with the aforementioned literature. Carbon dioxide, a product of yeast fermentation during beer production, has been reported to have inhibitory and stimulatory effects on microorganisms depending on the product and strain (Walsh et al. 2014). In this study, both free and immobilized L. brevis in beer were shown to be resistant to $\mathrm{CO}_{2}$ levels up to 2.8 volumes. $\mathrm{CO}_{2}$ creates an anaerobic environment and L. brevis was able to tolerate such conditions as it is a facultatively anaerobic microorganism (Vriesekoop et al. 2013).

The specific gravity, total soluble solids, $\mathrm{pH}$, and titratable acidity of beer with FLB and ILB are presented in Fig. 5. The specific gravity and total soluble solids on day 0 are similar to the values obtained for pure beer, while the $\mathrm{pH}$ and titratable acidity of pure beer were 4.66 and $1.80 \mathrm{mg} / \mathrm{mL}$ lactic acid, respectively. The significant changes in values during the initial days of storage may be due to the introduction of $L$. brevis cells which were adjusting to the conditions of the beer as well as the addition of a conditioning tablet. Specific gravity is a useful measurement in calculating the alcohol by volume of beer as it compares the density of a liquid to that of water. The final specific gravity after yeast fermentation is expected to be lower than the original specific gravity of the unfermented wort as the yeast has consumed most of the fermentable sugars, converting them to alcohol and leaving behind a proportion of starch that was not fermented (Bamforth 2004; Stange 2015). In this study, the wort had an original specific gravity of 1.04 and the resulting beer had a final specific gravity of 1.007. Using Eq. 1, the alcohol percent by volume was calculated to be $4.39 \%$. This agreed with the report of Bamforth (2004) stating that beer usually contains lower levels of ethanol compared to other alcoholic drinks with the UK mean alcohol content of $4.1 \%$ and the US average of $4.6 \%$. Moreover, during the storage period of the beer inoculated with probiotic bacteria, some yeast, and probiotic bacteria could have consumed the residual sugar, explaining the slightly decreasing trend in specific gravity until day 24 . No significant difference was observed in the SG of both types of beer.

The trend for the total soluble solids follows that of specific gravity with a final value of $6.2^{\circ}$ Brix for both beers. Brix scale measures the percentage of sugar and other dissolved solids in the solution. This value is also related to the alcohol content of beer (Ball 2006). Comparable to the trend for specific gravity, the increase in ${ }^{\circ}$ Brix from day 0 to day 3 could be attributed to the changing environment. Similarly, the slight decrease in total soluble solids during the 24-day storage period could be due to the consumption of the remaining sugar in the beer. Beer with FLB had a decrease of $0.45{ }^{\circ}$ Brix from day 3 to day 24, while the decrease was only 0.3 for beer with ILB. As explained by Zandi et al. (2016), free cells have easier access to sugar. In this study, however, no significant difference was observed between FLB and ILB at any storage time. These results indicated that immobilizing in DRP did not significantly affect the specific gravity, total soluble solids, and alcohol content of the beer.

The $\mathrm{pH}$ of pure beer was 4.66 and upon inoculation of the bacteria, this dropped to 4.40 for both beer with FLB and beer with ILB (Fig. 5). The decrease in $\mathrm{pH}$ coincided with the acid production by the lactic acid bacteria, which is similarly reported by Alcine Chan et al. (2019). The $\mathrm{pH}$ of both beers stayed at around 4.40 throughout the period of 24 days. This agreed with the values mentioned by Sakamoto and Konings (2003) stating that beer has $\mathrm{pH}$ from 3.8-4.7, making it an unfavorable medium for microbial growth. Controlling the $\mathrm{pH}$ of beer is necessary as $\mathrm{pH}$ influences beer flavor as well as physical and microbiological stability (Nimubona et al. 2013).

The general trend for titratable acidity was contrary to that for $\mathrm{pH}$, owing to the production of lactic acid. The lactic acid concentration was determined and expressed in terms of the predominant organic acid produced by $L$. brevis in the beer. The titratable acidity of pure beer on day 0 was $1.80 \mathrm{mg} / \mathrm{mL}$, this value increased to 4.27 and $4.64 \mathrm{mg} / \mathrm{mL}$ at day 3 for FLB and ILB, respectively. Titratable acidity of both beers after day 3 was relatively constant throughout time (Fig. 5). Beer with ILB had $4.59 \mathrm{mg} / \mathrm{mL}$ lactic acid after 24 days of storage compared to $4.26 \mathrm{mg} / \mathrm{mL}$ for beer with FLB. The titratable acidity 

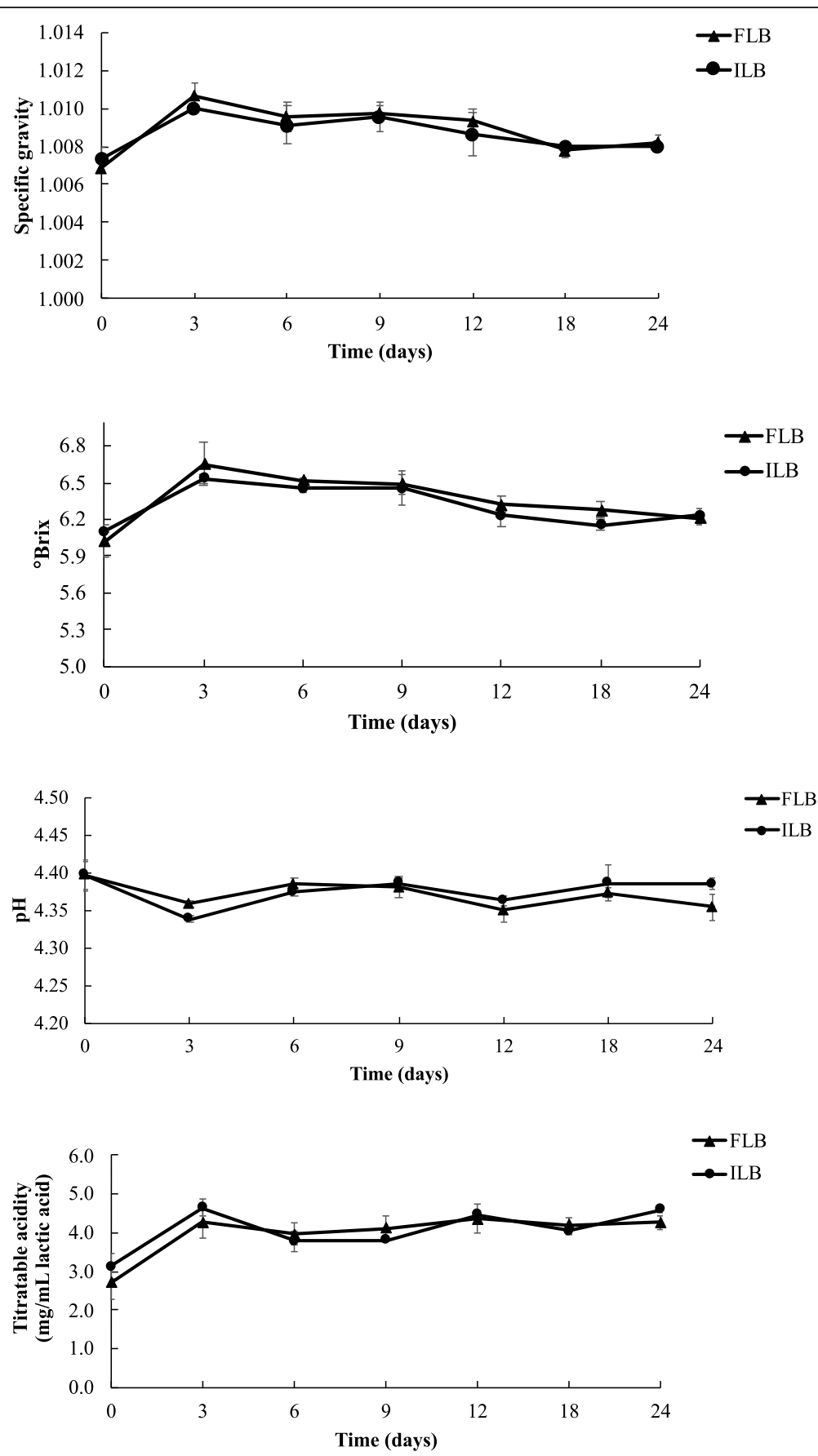

Fig. 5 Physico-chemical characteristics of beer with FLB and ILB. FLB $(\mathbf{-})=$ free L. brevis and ILB $(\mathbf{-})=$ immobilized L. brevis

of both beers in terms of lactic acid did not differ significantly for all sampling times, signifying that immobilization in DRP did not have a significant influence on lactic acid production. Lactic acid production can be attributed to the growth of probiotic bacteria, consequently decreasing the $\mathrm{pH}$ (Fig. 5). As demonstrated in Fig. 5, the residual sugar must have been consumed by the yeast as well as the lactic acid bacteria, similar to the results presented by Pakbin et al. (2014), thereby producing more lactic acid. Moreover, lactic acid production in the beer can be attributed to the growth of probiotic bacteria, consequently decreasing the $\mathrm{pH}$ of the substrate. Results showed that L. brevis both in free and immobilized states could survive and produce lactic acid in beer. 


\section{Viability of FLB and ILB in ale beer during storage at $21^{\circ} \mathrm{C}$}

Viability counts of $L$. brevis followed a propagation in culture which is a standard culture-based technique that has been widely used and is regarded as the only validated operational test to determine bacterial viability (Bogosian and Bourneuf 2001). Other techniques such as PCR or real-time PCR are unable to determine whether cells are viable or non-viable since these techniques cannot differentiate between DNA arising from live or dead cells (Cangelosi and Meschke 2014). Initial cell counts of FLB and ILB before inoculating into the beer were $8.92 \pm 0.04 \log \mathrm{CFU} / \mathrm{mL}$ and $9.94 \pm 0.04 \log \mathrm{CFU} / \mathrm{mL}$ of beer, respectively. Results showed that free and immobilized L. brevis manifested survival over the storage period of 24 days with the FLB count falling to $4.89 \mathrm{log}$ $\mathrm{CFU} / \mathrm{mL}$ and ILB having a count of $5.00 \mathrm{log} \mathrm{CFU} / \mathrm{mL}$ of beer at the end of 24 days (Fig. 6). The counts at day 0 for both FLB and ILB were significantly different from those for the other storage times. Immobilized cells had significantly higher counts than free cells at day 0 , day 6 , and day 12 of storage. On day 12, ILB had a count of $5.98 \log \mathrm{CFU} / \mathrm{mL}$ of beer which was significantly higher than the count for FLB. These results indicate that compared to the control, immobilization was able to effectively protect the $L$. brevis up to 12 days of storage at $21^{\circ} \mathrm{C}$ after which the counts decreased by $1 \log \mathrm{CFU} /$ $\mathrm{mL}$. Given that at least 1 million CFU of L. brevis were viable in the beer at ambient temperature during the storage period, the product has the potential to render probiotic benefits since it meets the minimun concentration $\left(10^{6} \mathrm{CFU} / \mathrm{mL}\right.$ or gram) required for a probiotic product to exert its beneficial effects (Kechagia et al. 2013).

While probiotic bacteria are generally reported to be susceptible to ethanol (G-Alegría et al. 2004), DRP in this study was shown to confer protection in $4.39 \% \mathrm{ABV}$ beer for up to 12 days. Immobilization has been described to be successful in protecting and improving the viability of probiotic bacteria (Mitropoulou et al. 2013). In the current study, L. brevis cells immobilized in DRP generally showed better survival compared to the control (free cells). Teh et al. (2009) suggested that the minerals and fibers present in durian rind supported the survival of probiotic bacteria. However, the difference between the viability of FLB and ILB was not significant at 24 days of storage. These results indicated that beer with free $L$. brevis or with cells immobilized on DRP could provide approximately $5 \log \mathrm{CFU} / \mathrm{mL}$ of beer. In a recent study utilizing probiotics as a starter culture in beer brewing, refrigeration was shown to better support the viability of the microorganisms compared to ambient storage (Alcine Chan et al. 2019). Since the present study simulated ambient storage, it is expected that the probiotics would be more viable at lower temperatures.

Data from this investigation suggested that both FLB and ILB were able to tolerate ale beer conditions including the presence of ethanol and hop acids. In general, Lactobacilli are shown to be tolerant to $4 \%$ ethanol (Gold et al. 1992). In such a study, strains of L. brevis were reported to be tolerant to the said percentage but the tolerance decreased at $8 \%$ ethanol levels. Ethanol tolerance has been attributed to the stimulation of the release of stress proteins and changes in the fatty acid profile of the cell membrane (Gold et al. 1992; Yomano et al. 1998). This suggested a possible correlation between abnormality in the cellular lipids and characteristic ethanol tolerance of the microorganism as described by Uchida and Mogi (1973). Nonetheless, employing a more alcohol-tolerant L. brevis strain, a higher initial probiotic count, and refrigerated conditions can be explored in the future. Furthermore, despite the known antimicrobial activity of hop compounds, L. brevis strains are considered to be resistant due to immunity

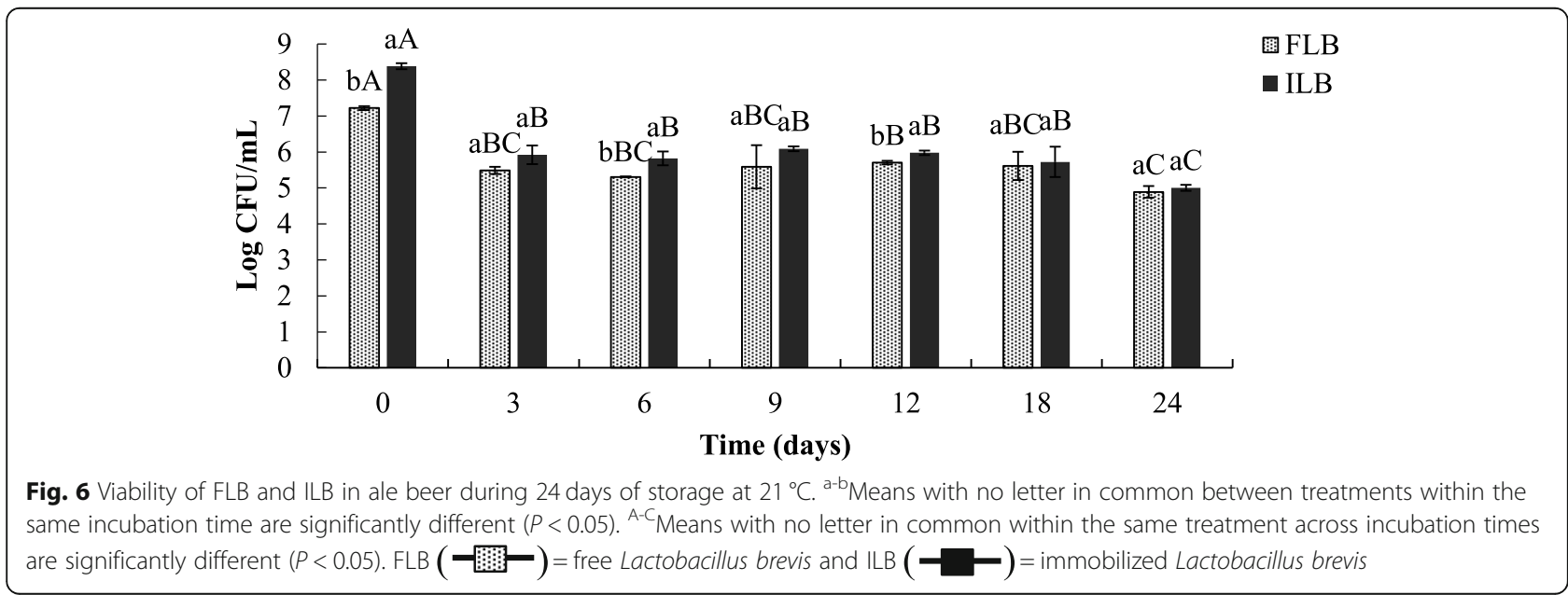


developed from prolonged contact with hop compounds during brewing. This hop resistance was associated with changes in membrane lipid components (Sakamoto and Konings 2003). Behr et al. (2007) further explained hop resistance mechanisms, including proton motive force depletion as well as complex changes in metabolism and structural improvements of cell wall components. Probiotic strains were not viable in hopped wort as shown recently (Alcine Chan et al. 2019), but the current study revealed the survival of L. brevis in hopped wort, signifying hop tolerance of the microorganism used. To the best of the authors' knowledge, this is the first study demonstrating the survival of probiotic bacteria in hopped fermented wort in the production of ale beer. The recent study by Alcine Chan et al. (2019) employed co-fermentation of unhopped wort with yeast and probiotic bacteria. Our study was able to manifest the survival of the L. brevis even in hopped wort.

Another possible scenario could be the enhancement of probiotic survival due to the presence of yeast, possibly forming biofilms that protected the lactic acid bacteria from external stress conditions. A combination of live S. cerevisiae S-04 and probiotic L. paracasei L26 in beer during refrigerated storage was shown to maximize probiotic viability (Alcine Chan et al. 2019).

\section{Viability in simulated gastric and intestinal fluids of FLB and ILB in ale beer stored for 24 days at $21{ }^{\circ} \mathrm{C}$}

Figure 7 presents the probiotic viability in SGF and SIF. The $\mathrm{pH}$ conditions used in this study were in agreement with the report of Vandamme et al. (2002), which suggested that dosage forms must start passing through the stomach $(\mathrm{pH} 1.5-3.5)$ to the colon with $\mathrm{pH}$ ranging from 6.4 in the ascending colon to 7.0 in the descending colon. Lactobacillus strains must survive at least at $\mathrm{pH}$ 3.0 in the stomach (Fernandez et al. 2003). Survival at $\mathrm{pH} 3.0$ for $2 \mathrm{~h}$ was reported to be the standard for optimal acid tolerance of probiotic strains (Liong and Shah 2005). Using the same $\mathrm{pH}$ condition, FLB and ILB in beer stored for 24 days had counts of 4.63 and $4.70 \mathrm{log}$ $\mathrm{CFU} / \mathrm{mL}$ of beer, respectively, after $120 \mathrm{~min}$ of exposure to SGF. These results were in accordance with findings from Sahadeva et al. (2011) which demonstrated that the survival of some Lactobacillus strains was due to the $\mathrm{pH}$ not causing the complete destruction of all the cells. Since disruption of metabolic and cytoplasmic activities normally restrict survival of probiotics under acidic conditions for $2 \mathrm{~h}$ (Kim et al. 2016), current results indicated that FLB and ILB met the criterion for gastric acid resistance.

Teh et al. (2009) postulated that immobilization on agrowastes, including durian rind, allows for higher stability in acidic conditions. The presence of cellulose in DRP could account for partial protection. Xiudong et al.
(2016) found that adsorbing Lactobacillus cells on or entrapping them in bacterial cellulose was effective in protecting the probiotics in simulated gastric juices. Additionally, FLB and ILB in beer stored for 24 days had counts of 4.64 and $5.14 \log \mathrm{CFU} / \mathrm{mL}$ of beer, respectively, after $120 \mathrm{~min}$ of exposure to SIF. The polysaccharide nature of DRP could account for its dissolution by enzymatic hydrolysis upon reaching the small intestine to deliver the probiotic bacteria into the colon as described by Govender et al. (2014). Results showed that ILB had higher viable counts than FLB in simulated gastric and intestinal conditions at the end of storage but the differences were not significant. The slightly higher counts obtained for ILB after exposure to SIF compared to the initial concentration suggest the possible presence of new microbial species as explained in the succeeding section.

\section{Microbial diversity of beer with FLB and ILB}

bTEFAP was used to evaluate the microbial diversity of beer with FLB and ILB. This method has been used for the determination of bacteria and fungi present in different materials as described in different studies (Guass et al. 2016; Schmidt et al. 2018; Tekin et al. 2017). For bacteria, a total of 1,068,631 and 1,084,617 sequences were analyzed for beer with FLB and beer with ILB, respectively (Fig. 8). For fungi, 255,326 and 259,741 sequences were analyzed for beer with FLB and beer with ILB, respectively (Table 2). At the genus level, Lactobacilli were the most dominant bacteria and Saccharomyces were the most dominant fungi in both beers. Results showed that the predominant species present in both types of beer was $L$. brevis, which was the probiotic bacteria inoculated. At 24 days of storage at $21^{\circ} \mathrm{C}$, L. brevis was present at 61.88 and $55.68 \%$ in beer with FLB and beer with ILB, respectively. An interesting finding was the presence of $L$. farciminis at 35.31 and $41.63 \%$ in beer with FLB and beer with ILB, respectively, following $L$. brevis among the bacterial species identified. $L$. farciminis is a halophilic obligately homofermentative lactic acid bacterium that is closely related to $\mathrm{L}$. alimentarius (Lee et al. 2010; Rachman et al. 2003; Yoon et al. 2018). It is considered as a probiotic microorganism with reported health benefits in suppressing stress-induced hypersensitivity. One study hypothesized that this mechanism is linked to the bacteria's protective effect on the intestinal barrier. This species was also the first probiotic found to suppress stressinduced visceral hypersensitivity in rats, suggesting the use of the strain in managing irritable bowel syndrome (Eutamene et al. 2009). Since this species is typically part of kimchi fermentation, it can act as a probiotic (Lee et al. 2010). Data from our study indicated that the ale beer conditions including the 


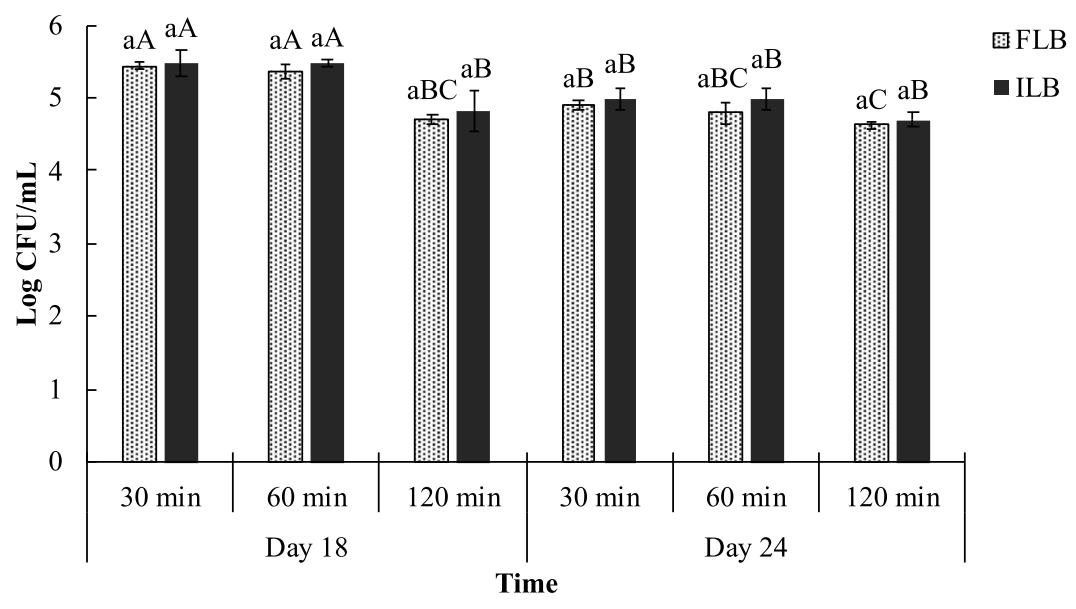

SIF

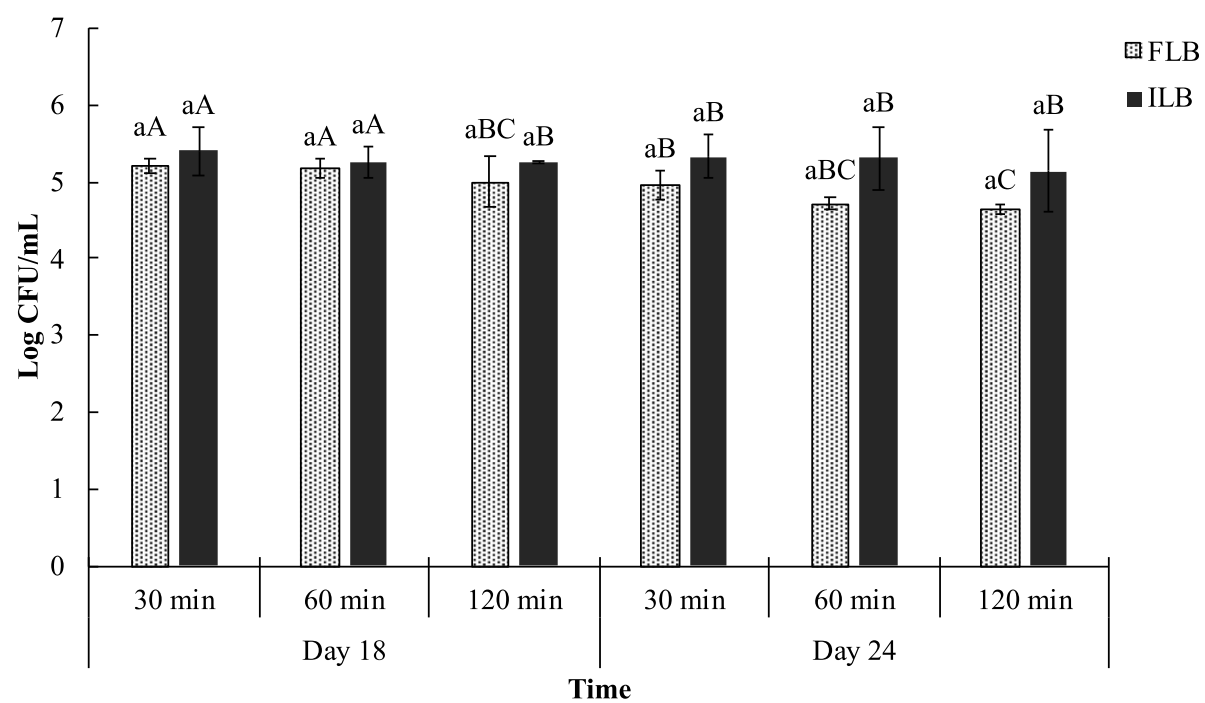

Fig. 7 Viability of FLB and ILB in ale beer during 24 days of storage at $21^{\circ} \mathrm{C}$ followed by exposure to SGF $(\mathrm{pH}=3.0)$ and SIF (pH=6.5). ${ }^{\mathrm{a}}$ Means with no letter in common between treatments within the same incubation time are significantly different $(P<0.05)$. ${ }^{A-C}$ Means with no letter in common within the same treatment across incubation times are significantly different $(P<0.05)$. FLB $\left(-\mathrm{FlF}_{-}-\right)=$free Lactobacillus brevis and ILB $(-)=$ immobilized Lactobacillus brevis

presence of $L$. brevis might have stimulated the growth of L. farciminis until the end of the storage period, with the latter having a slightly higher relative proportion when immobilized in DRP. While the microbial counts obtained from plating may have taken into account $L$. farciminis, the microbial diversity at different points of fermentation needs to be explored further. Nonetheless, the most dominant L. brevis and L. farciminis are probiotic strains, which show the potential for providing health benefits to beer consumers. Other bacterial species were present in minute amounts as shown in Fig. 8.
In this study, the fungal microbiome was characterized as presented in Table 2. Sequences associated with $S$. cerevisiae represented at least $99.9 \%$ in both beers. In a study by Spitaels et al. (2014), S. cerevisiae was the most prevalent species until 2 weeks of fermentation of lambic beer. Other fungal species were detected at less than $0.1 \%$ of the sequences using bTEFAP.

From this approach, it is proposed to study the synergistic relationships among the microbial communities present as well as the correlations between the abundance of particular microbes and the production of certain metabolites. Specific microorganisms may play a 


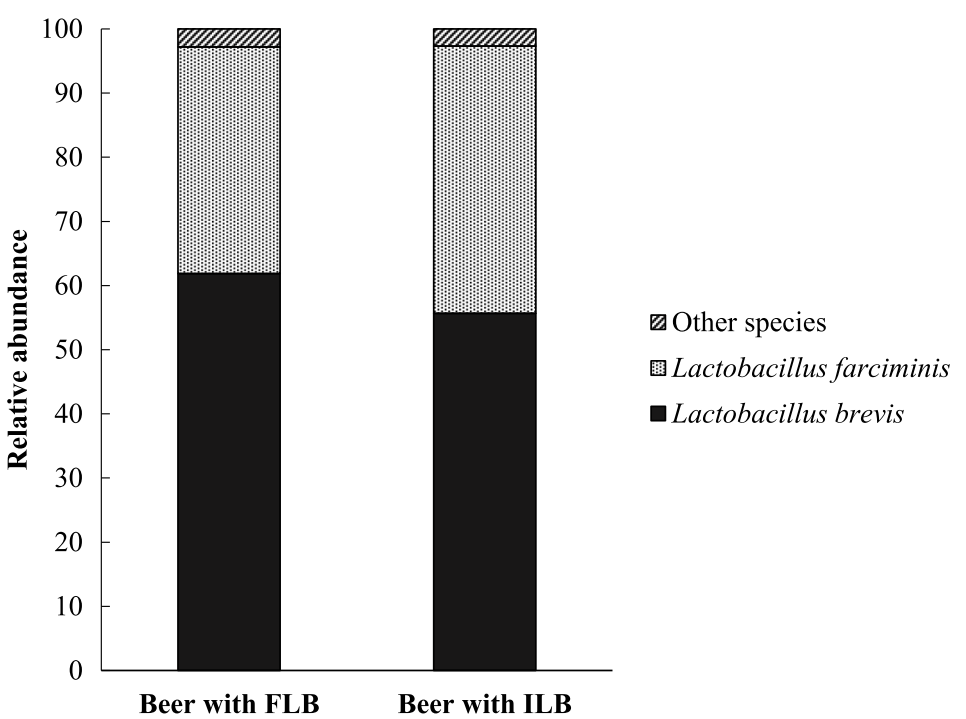

Fig. 8 Relative abundance of bacteria in beer with FLB (free Lactobacillus brevis) and ILB (immobilized Lactobacillus brevis) at the species

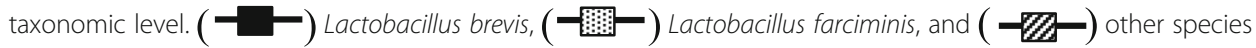

role in metabolite production at different stages of beer production. The causality between the microbial diversity and organoleptic properties, such as beer flavor, can eventually be determined. Omics can therefore also be used to emphasize genes that are responsible for the health-associated benefits of the probiotic bacteria present (Walsh et al. 2016).

\section{Conclusions}

Ale beer containing free L. brevis and cells immobilized in DRP was developed. SEM micrographs illustrated random distribution and attachment of bacterial cells to DRP. The specific gravity, total soluble solids, $\mathrm{pH}$, and titratable acidity of beer with FLB and beer with ILB did not differ significantly between the beers at 24 days of storage at $21^{\circ} \mathrm{C}$. ILB had significantly higher counts at day 0 , day 6 , and day 12 , demonstrating that DRP conferred protection up to 12 days of ambient storage. However, the counts were not significantly different at the end of the storage period. The differences were not significant in simulated gastric and intestinal conditions, implying that beer with both forms of L. brevis could supply approximately $5 \log \mathrm{CFU} / \mathrm{mL}$. Results showed that the predominant species was L. brevis at 61.88 and

Table 2 Relative abundance of fungi in beer with FLB and ILB at the species taxonomic level

\begin{tabular}{llll}
\hline Genus & Species & Beer with FLB & Beer with ILB \\
\hline Saccharomyces & cerevisiae & 99.9 & 99.8 \\
Brettanomyces & bruxellensis & 0.05 & 0.04 \\
& Other species & 0.02 & 0.05 \\
\hline
\end{tabular}

$55.68 \%$ in beer with FLB and beer with ILB, respectively, followed by $L$. farciminis with respective relative percentages of 35.31 and $41.63 \%$. Sequences with S. cerevisiae represented at least $99.99 \%$ in both beers. In conclusion, ale beer containing free L. brevis and immobilized cells in durian rind powder has potential as a delivery system for probiotics. Future research is needed to investigate the organoleptic properties and consumer acceptability of the beer as well as the cell viability in refrigerated conditions. It is important to highlight that in this study, no health benefits from the potential delivery system were investigated. However, it would be important in the future to investigate the effectiveness of the probiotic delivery system and its influence on gut microbiota and gut inflammation using in vivo models.

\section{Abbreviations}

ADF: Acid detergent fiber; bTEFAP: Bacterial tag-encoded FLX amplicon pyrosequencing; FLB: Free Lactobacillus brevis; ILB: Immobilized Lactobacillus brevis; DRP: Durian rind powder; MRS: De Man, Rogosa, and Sharpe;

OTUs: Operational taxonomic units; SEM: Scanning electron microscopy; SG: Specific gravity; SGF: Simulated gastric fluid; SIF: Simulated intestinal fluid

\section{Acknowledgments}

Ms. Kriza Calumba is grateful to the Fulbright-CHED Philippines scholarship program and the University of the Philippines Mindanao for allowing her to pursue graduate studies at Louisiana State University.

Authors' contributions

SS and KFC designed the study. KFC, FB, VR, and EV performed the experiments and obtained the data. KFC and EV analyzed and interpreted the results. KFC wrote the article. All authors read and approved the final manuscript. 


\section{Availability of data and materials}

All data generated during this study are included in this published article. Further details are available from the corresponding author on reasonable request.

\section{Ethics approval and consent to participate}

Not applicable.

\section{Consent for publication}

Not applicable.

\section{Competing interests}

The authors declare that they have no competing interests.

Received: 13 August 2020 Accepted: 12 January 2021

Published online: 01 March 2021

\section{References}

Alcine Chan, M. Z., Chua, J. Y., Toh, M., \& Liu, S. Q. (2019). Survival of probiotic strain Lactobacillus paracasei L26 during co-fermentation with S. cerevisiae for the development of a novel beer beverage. Food Microbiology, 82(April), 541-550 https://doi.org/10.1016/j.fm.2019.04.001.

AOAC (Association of Official Analytical Chemists) (1990). Ash of Animal Feed. AOAC Official Method 942.05. Arlington.

AOAC (Association of Official Analytical Chemists) (1995). Protein (Crude) in Animal Feeds. AOAC Official Method 976.06. Arlington.

AOAC (Association of Official Analytical Chemists) (2006). Crude Fat in Feeds, Cereal Grains, and Forages. AOAC Official Method 2003.06. Arlington.

Augustin, M. A., \& Sanguansri, L. (2015). Challenges and solutions to incorporation of nutraceuticals in foods. Annual Review of Food Science and Technology, 6(1), 463-477 https://doi.org/10.1146/annurev-food-022814-015507.

Ball, D. W. (2006). Concentration scales for sugar solutions. Journal of Chemical Education, 83(10), 1489-1491.

Bamforth, C. W. (2004). Beer: Health and nutrition, (-Ames, lowa). Blackwell Science Ltd. Oxford.

Beer Judge Certification Program (2015). 2015 style guidelines. Retrieved from https://www.bjcp.org/docs/2015_Guidelines_Beer.pdf.

Behr, J., Israel, L., Gänzle, M. G., \& Vogel, R. F. (2007). Proteomic approach for characterization of hop-inducible proteins in Lactobacillus brevis. Applied and Environmental Microbiology, 73(10), 3300-3306 https://doi.org/10.1128/AEM. 00124-07.

Bishehsari, F., Magno, E., Swanson, G., Desai, V., Voigt, R. M., Forsyth, C. B., \& Keshavarzian, A. (2017). Alcohol and gut-derived inflammation. Alcohol Research: Current Reviews, 38(2), 163.

Bogosian, G., \& Bourneuf, E. V. (2001). A matter of bacterial life and death. EMBO Reports, 2(9), 770-774 https://doi.org/10.1093/embo-reports/kve182.

Bradford, R., Reyes, V., Bonilla, F., Bueno, F., Dzandu, B., Liu, C., ... Sathivel, S. (2019). Development of milk powder containing Lactobacillus plantarum NCIMB 8826 immobilized with prebiotic hi-maize starch and survival under simulated gastric and intestinal conditions. Food Production, Processing and Nutrition, 1(1), 1-8 https://doi.org/10.1186/s43014-019-0011-6.

Brick, J. (2006). Standardization of alcohol calculations in research. Alcoholism: Clinical and experimental research, 30(8), 1276-1287 https://doi.org/10.1111/j. 1530-0277.2006.00155.x

Cangelosi, G. A., \& Meschke, J. S. (2014). Dead or alive: Molecular assessment of microbial viability. Applied and Environmental Microbiology, 80(19), 5884-5891 https://doi.org/10.1128/AEM.01763-14.

Colen, L., \& Swinnen, J. (2016). Economic growth, globalisation and beer consumption. Journal of Agricultural Economics, 67(1), 186-207 https://doi. org/10.1111/1477-9552.12128.

da Silva, G. A., Augusto, F., \& Poppi, R. J. (2008). Exploratory analysis of the volatile profile of beers by HS-SPME-GC. Food Chemistry, 111(4), 1057-1063 https:// doi.org/10.1016/j.foodchem.2008.05.022.

Dowd, S. E., Callaway, T. R., Wolcott, R. D., Sun, Y., McKeehan, T., Hagevoort, R. G. \& Edrington, T. S. (2008). Evaluation of the bacterial diversity in the feces of cattle using $16 \mathrm{~S}$ rDNA bacterial tag-encoded FLX amplicon pyrosequencing (bTEFAP). BMC Microbiology, 8, 1-8 https://doi.org/10.1186/1471-2180-8-125.

El Enshasy, H., \& Moawad, H. (2011). $\beta$-glucanase productivity improvement via cell immobilization of recombinant Escherichia coli cells in different matrices, (January 2016).
Elez-Martinez, P., Escola-Hernandez, J., Soliva-Fortuny, R., \& Martin-Belloso, O. (2005). Inactivation of Lactobacillus brevis in orange juice by high-intensity pulsed electric fields. Food Microbiology, 22(4), 311-319 https://doi.org/10. 1016/j.fm.2004.09.005.

Engen, P. A., Green, S. J., Voigt, R. M., Forsyth, C. B., \& Keshavarzian, A. (2012). The gastrointestinal microbiome, $(C d c)$.

EPA (Environmental Protection Agency) (1993). Determination of Total Kjeldahl Nitrogen by Semi-Automated Colorimetry. Method 351.2. Cincinnati, OH.

Espino, R. R. C., \& Espino, M. R. C. (2014). The Status of the Fruit Industry in the Philippines, (pp. 1-21) Retrieved from http://www.fftc.agnet.org/library. php?func=view\&style=type\&id $=20150810090507$.

Eutamene, H., Houdeau, E., Bueno, L., Fioramonti, J., \& Theodorou, V. (2009). Lactobacillus farciminis treatment attenuates stress-induced overexpression of Fos protein in spinal and supraspinal sites after colorectal distension in rats, (December 2008). https://doi.org/10.1111/j.1365-2982.2009.01280.x.

Fernandez, M. F., Boris, S., \& Barbes, C. (2003). Probiotic properties of human lactobacilli strains to be used in the gastrointestinal tract. Journal of Applied Microbiology, 94, 449-455

Foo, K. Y., \& Hameed, B. H. (2011). Transformation of durian biomass into a highly valuable end commodity: Trends and opportunities. Biomass and Bioenergy, 35(7), 2470-2478 https://doi.org/10.1016/jbiombioe.2011.04.004.

Food and Agriculture Organization (FAO) and World Health Organization (WHO) (2002). Report of a Joint FAO/WHO working group on drafting guidelines for the evaluation of probiotics in food. In Guidelines for the evaluation of probiotics in food.

G-Alegría, E., López, I., Ruiz, J. I., Sáenz, J., Fernández, E., Zarazaga, M., ... RuizLarrea, F. (2004). High tolerance of wild Lactobacillus plantarum and Oenococcus oeni strains to lyophilisation and stress environmental conditions of acid pH and ethanol. FEMS Microbiology Letters, 230(1), 53-61 https://doi.org/10.1016/S0378-1097(03)00854-1.

Gold, R. S., Meagher, M. M., Hutkins, R., \& Conway, T. (1992). Ethanol tolerance and carbohydrate metabolism in lactobacilli. Journal of Industrial Microbiology, 10(1), 45-54 https://doi.org/10.1007/BF01583633.

Govender, M., Choonara, Y. E., Kumar, P., du Toit, L. C., van Vuuren, S., \& Pillay, V. (2014). A review of the advancements in probiotic delivery: Conventional vs. non-conventional formulations for intestinal Flora supplementation. AAPS PharmSciTech, 15(1), 29-43 https://doi.org/10.1208/s12249-013-0027-1.

Guass, O., Haapanen, L. M., Dowd, S. E., Širović, A., \& McLaughlin, R. W. (2016). Analysis of the microbial diversity in faecal material of the endangered blue whale, Balaenoptera musculus. Antonie van Leeuwenhoek, International Journal of General and Molecular Microbiology, 109(7), 1063-1069 https://doi. org/10.1007/s10482-016-0698-1.

Guo, W., Jia, W., Li, Y., \& Chen, S. (2010). Performances of Lactobacillus brevis for Producing Lactic Acid from Hydrolysate of Lignocellulosics. Applied biochemistry and biotechnology, 1, 124-136 https:/doi.org/10.1007/s12010-009-8857-8.

Hameed, B. H., \& Hakimi, H. (2008). Utilization of durian (Durio zibethinus Murray) peel as low cost sorbent for the removal of acid dye from aqueous solutions. Biochemical Engineering Journal, 39(2), 338-343 https://doi.org/10.1016/j.bej. 2007.10.005.

Hove, H., Norgaard, H., \& Mortensen, P. B. (2014). Lactic acid bacteria and the human gastrointestinal tract. Lactic Acid Bacteria: Fundamentals and Practice, 375-441 https://doi.org/10.1007/978-94-017-8841-0_6.

Jagannath, A., Raju, P. S., \& Bawa, A. S. (2010). Comparative evaluation of bacterial cellulose ( nata ) as a cryoprotectant and carrier support during the freeze drying process of probiotic lactic acid bacteria q. LWT - Food Science and Technology, 43(8), 1197-1203 https://doi.org/10.1016/j.lwt. 2010.03.009.

Jia, K., Zhang, Y., \& Li, Y. (2010). Systematic engineering of microorganisms to improve alcohol tolerance. Engineering in Life Sciences, 10(5), 422-429 https:// doi.org/10.1002/elsc.201000076.

Kechagia, M., Basoulis, D., Konstantopoulou, S., Dimitriadi, D., Gyftopoulou, K., Skarmoutsou, N., \& Fakiri, E. M. (2013). Health benefits of probiotics: A review. International Scholarly Research Notices, 2013, 1-7 https://doi.org/10.5402/ 2013/481651.

Kha, T. C., Nguyen, M. H., \& Roach, P. D. (2010). Effects of spray drying conditions on the physicochemical and antioxidant properties of the Gac ( Momordica cochinchinensis ) fruit aril powder. Journal of Food Engineering, 98(3), 385392 https://doi.org/10.1016/j.jfoodeng.2010.01.016.

Kim, J., Muhammad, N., Jhun, B. H., \& Yoo, J. W. (2016). Probiotic delivery systems: A brief overview. Journal of Pharmaceutical Investigation, 46(4), 377-386 https://doi.org/10.1007/s40005-016-0259-7. 
Kimoto-nira, H., Suzuki, S., Suganuma, H., \& Moriya, N. (2015). Anaerobe growth characteristics of Lactobacillus brevis KB290 in the presence of bile. YANAE, 35, 96-101 https://doi.org/10.1016/j.anaerobe.2015.08.001.

Knoshaug, E. P., \& Zhang, M. (2009). Butanol tolerance in a selection of microorganisms. Applied Biochemistry and Biotechnology, 153(1-3), 13-20 https://doi.org/10.1007/s12010-008-8460-4.

Lee, M. K., Ku, K. H., Kim, Y. J., Kim, K. H., Kim, Y. R., \& Yang, H. J. (2010). Development of species-specific primers for pcr identification of lactobacillus hilgardii and lactobacillus farciminis in kimchi. Journal of Food Science and Nutrition, 15(2), 159-166 https://doi.org/10.3746/jfn.2010.15.2.159.

Liong, M. T., \& Shah, N. P. (2005). Acid and bile tolerance and cholesterol removal ability of lactobacilli strains. Journal of Dairy Science, 88(1), 55-66 https://doi. org/10.3168/jds.S0022-0302(05)72662-X.

Lordan, R., O'Keeffe, E., Tsoupras, A., \& Zabetakis, I. (2019). Total, neutral, and polar lipids of brewing ingredients, by-products and beer: Evaluation of antithrombotic activities. Foods, 8(5), 171 https://doi.org/10.3390/foods8050171.

Madhu, C., Krishna, K. M., Reddy, K. R., \& Lakshmi, P. J. (2017). Estimation of crude fibre content from natural food stuffs and its laxative activity induced in rats. Int J Pharma Res Health Sci, 5(3), 1703-1706 https://doi.org/10.21276/ijprhs.2017.03.04.

Martínez, A., Vegara, S., Herranz-López, M., Martí, N., Valero, M., Micol, V., \& Saura, D. (2017). Kinetic changes of polyphenols, anthocyanins and antioxidant capacity in forced aged hibiscus ale beer. Journal of the Institute of Brewing, 123(1), 58-65 https://doi.org/10.1002/jib.387.

Masrol, S. R., Ibrahim, M. H. I., \& Adnan, S. (2015). Chemi-mechanical pulping of durian rinds. Procedia Manufacturing, 2(February), 171-180 https://doi.org/10. 1016/j.promfg.2015.07.030

Mis, K., Chouljenko, A., Chotiko, A., \& Sathivel, S. (2019). Growth kinetics and lactic acid production of Lactobacillus plantarum NRRL B-4496, L. acidophilus NRRL B-4495, and L. reuteri B-14171 in media containing egg white hydrolysates. LWT - Food Science and Technology, 105, 393-399 https://doi.org/10.1016/j.lwt.2019.01.058.

Mitropoulou, G., Nedovic, V., Goyal, A., \& Kourkoutas, Y. (2013). Immobilization technologies in probiotic food production. Journal of Nutrition and Metabolism, 2013 https://doi.org/10.1155/2013/716861.

Nedovic, V., \& Willaert, R. (2005). Applications of Cell Immobilisation Biotechnology, (vol. 8B) https://doi.org/10.1007/1-4020-3363-X.

Nimubona, D., Blanco, C. A., Caballero, I., Rojas, A., \& Andrés-Iglesias, C. (2013). An approximate shelf life prediction of elaborated lager beer in terms of degradation of its iso-a-acids. Journal of Food Engineering, 116(1), 138-143 https://doi.org/10.1016/j.jfoodeng.2012.11.019.

Nuithitikul, K., Srikhun, S., \& Hirunpraditkoon, S. (2010). Kinetics and equilibrium adsorption of basic Green 4 dye on activated carbon derived from durian peel: Effects of pyrolysis and post-treatment conditions. Journal of the Taiwan Institute of Chemical Engineers, 41(5), 591-598 https://doi.org/10.1016/j.jtice.2010.01.007.

Pakbin, B., Razavi, S. H., Mahmoudi, R., \& Gajarbeygi, P. (2014). Producing probiotic peach juice, (November). https://doi.org/10.17795/bhs-24683.

Parker, D. K. (2012). 6 - Beer: Production, sensory characteristics and sensory analysis. In J. B. T.-A. B. P. Piggott (Ed.), Woodhead Publishing Series in Food Science, Technology and Nutrition, (pp. 133-158). Woodhead Publishing https://doi.org/10.1533/9780857095176.2.133.

Penjumras, P., Rahman, R. B. A., Talib, R. A., \& Abdan, K. (2014). Extraction and characterization of cellulose from durian rind. Agriculture and Agricultural Science Procedia, 2, 237-243 https://doi.org/10.1016/j.aaspro.2014.11.034.

Perricone, M., Bevilacqua, A., Altieri, C., Sinigaglia, M., \& Corbo, M. (2015). Challenges for the production of probiotic fruit juices. Beverages, 1(2), 95-103 https://doi.org/10.3390/beverages1020095.

Rachman, C. N., Kabadjova, P., Prevost, H., \& Dousset, X. (2003). Identification of Lactobacillus alimentarius and Lactobacillus farciminis with 165 - 23S rDNA intergenic spacer region polymorphism and PCR amplification using speciesspecific oligonucleotide. Journal of applied microbiology, 95(6), 1207-1216 https://doi.org/10.1046/j.1365-2672.2003.02117.x.

Raghavendra, S. N., Swamy, S. R. R., \& Rastogi, N. K. (2006). Grinding characteristics and hydration properties of coconut residue : A source of dietary fiber. Journal of Food Engineering, 72, 281-286 https://doi.org/10.1016/j.jfoodeng.2004.12.008

Reyes, V., Chotiko, A., Chouljenko, A., \& Sathivel, S. (2018). Viability of Lactobacillus acidophilus NRRL B-4495 encapsulated with high maize starch, maltodextrin, and gum arabic. LWT - Food Science and Technology, 96(March), 642-647 https://doi.org/10.1016/j.lwt.2018.06.017.

Roberts, D., Reyes, V., Bonilla, F., Dzandu, B., Liu, C., Chouljenko, A., \& Sathivel, S. (2018). Viability of Lactobacillus plantarum NCIMB 8826 in fermented apple juice under simulated gastric and intestinal conditions. LWT - Food Science and Technology, 97(April), 144-150 https://doi.org/10.1016/j.lwt.2018.06.036.
Rohner, R. L., \& Tompkins, J. R. (1970). Continuous automatic control of carbonation in beer streams. In Proceedings. Annual meeting - American Society of Brewing Chemists https://doi.org/10.1080/00960845.1970.12006968.

Sahadeva, R. P. K., Leong, S. F., Chua, K. H., Tan, C. H., Chan, H. Y., Tong, E. V., .. Chan, H. K. (2011). Survival of commercial probiotic strains to $\mathrm{pH}$ and bile. International Food Research Journal, 18(4), 1515-1522.

Sakamoto, K., \& Konings, W. N. (2003). Beer spoilage bacteria and hop resistance. International Journal of Food Microbiology, 89(2-3), 105-124 https://doi.org/ 10.1016/S0168-1605(03)00153-3.

Schmidt, J. M., Henken, S., Dowd, S. E., \& McLaughlin, R. W. (2018). Analysis of the microbial diversity in the fecal material of giraffes. Current Microbiology, 75(3), 323-327 https://doi.org/10.1007/s00284-017-1383-y.

Shyamala, B., \& Jamuna, P. (2010). Nutritional content and antioxidant properties of pulp waste from Daucus carota and Beta vulgaris. Malaysian Journal of Nutrition, 16(3), 397-408.

Spitaels, F., Wieme, A. D., Janssens, M., Aerts, M., Daniel, H. M., Van Landschoot, A., ... Vandamme, P. (2014). The microbial diversity of traditional spontaneously fermented lambic beer. PLoS One, 9(4) https://doi.org/10.1371/journal.pone. 0095384.

Stange, B. (2015). Specific gravity: How to measure it when brewing beer. Retrieved from https://learn.kegerator.com/specific-gravity/

Teh, S. S., Rosma, A., Wan-Abdullah, W. N., \& Min-Tze, L. (2009). Evaluation of agrowastes as immobilizers for probiotics in soy milk. Journal of Agricultural and Food Chemistry, 57(21), 10187-10198 https://doi.org/10.1021/jf902003a.

Tekin, S., Dowd, S. E., Davinic, M., Bursali, A., \& Keskin, A. (2017). Pyrosequencing based assessment of bacterial diversity in Turkish Rhipicephalus annulatus and Dermacentor marginatus ticks (Acari: Ixodidae). Parasitology Research, 116(3), 1055-1061 https://doi.org/10.1007/s00436-017-5387-0.

Uchida, K., \& Mogi, K. (1973). Cellular fatty acid spectra of hiochi bacteria, alcoholtolerant lactobacilli, and their group separation. The Journal of General and Applied Microbiology, 249, 233-249.

Unhasirikul, M., Naranong, N., \& Narkrugsa, W. (2012). Reducing sugar production from durian peel by hydrochloric acid hydrolysis. World Academy of Science, Engineering and Technology, 6(9), 394-399 https://doi.org/scholar.waset.org/1999.1/12589.

Vandamme, T. F., Lenourry, A., Charrueau, C., Chaumeil, J., \& Rene, Â. (2002). The use of polysaccharides to target drugs to the colon, (p. 48).

Vasudha, S., \& Mishra, H. N. (2013). Non dairy probiotic beverages. International Food Research Journal, 20(1), 7-15.

Vijaya Kumar, B., Vijayendra, S. V. N., \& Reddy, O. V. S. (2015). Trends in dairy and non-dairy probiotic products - a review. Journal of Food Science and Technology, 52(10), 6112-6124 https://doi.org/10.1007/s13197-015-1795-2.

Vriesekoop, F., Krahl, M., Hucker, B., \& Menz, G. (2013). 125th anniversary review : Bacteria in brewing: The good, the bad, and the ugly. Journal of the Institute of Brewing, November, 2012, 335-345 https://doi.org/10.1002/jib.49.

Walsh, A. M., Crispie, F., Kilcawley, K., O'Sullivan, O., O'Sullivan, M. G., Claesson, M. J., \& Cotter, P. D. (2016). Microbial succession and flavor production in the fermented dairy beverage kefir. Applied and Environmental Science, 1(5), 1-16 https://doi.org/10.1128/mSystems.00052-16.Editor.

Walsh, H., Cheng, J., \& Guo, M. (2014). Effects of carbonation on probiotic survivability, physicochemical, and sensory properties of milk-based symbiotic beverages. Journal of Food Science, 79(4), M604-M613 https://doi. org/10.1111/1750-3841.12381.

Xiudong, X., Ying, W., Xiaoli, L., Ying, L., \& Jianzhong, Z. (2016). Soymilk residue (okara) as a natural immobilization carrier for Lactobacillus plantarum cells enhances soymilk fermentation, glucosidic isoflavone bioconversion, and cell survival under simulated gastric and intestinal conditions. PeerJ, 4, e2701 https://doi.org/10.7717/peerj.2701.

Yomano, L. P., York, S. W., \& Ingram, L. O. (1998). Isolation and characterization of ethanoltolerant mutants of Escherichia coli KO11 for fuel ethanol production, (pp. 132-138).

Yoon, J., Kang, S., Mheen, T., Ahn, J., Lee, H., Kim, T., ... Park, Y. (2018). Lactobacillus kimchii sp. nov., a new species from kimchi, (2000), (pp. 1789-1795).

Zandi, M. M., Hashemiravan, M., \& Berenjy, S. (2016). Production of probiotic fermented mixture of carrot. Beet and Apple Juices, 7, 17-23.

Zhao, J., Bai, Y., Tao, S., Zhang, G., Wang, J., Liu, L., \& Zhang, S. (2019). Fiber-rich foods affected gut bacterial community and short-chain fatty acids production in pig model. Journal of Functional Foods, 57(April), 266-274 https://doi.org/10.1016/j.jf.2019.04.009.

\section{Publisher's Note}

Springer Nature remains neutral with regard to jurisdictional claims in published maps and institutional affiliations. 